\title{
Porchat e o caminho aos principios
}

\author{
Marco Zingano \\ Universidade de São Paulo USP
}

\section{RESUMO}

O texto busca apresentar a discussão em torno de Ciência e Dialética em Aristóteles, de Porchat.

\section{PALAVRAS-CHAVE}

Aristóteles; Filosofia antiga.

\section{ABSTRACT}

The text seeks to present the discussion around Science and Dialectic in Aristotle, by Porchat.

\section{KEY WORDS}

Aristoteles; Ancient Philosophy. 
O título deste texto, Porchat e o caminho aos princípios, faz obviamente referência à tese de Porchat, defendida em 1967 na USP. A tese consistia em um exame acurado dos Segundos Analíticos de Aristóteles e visava a aquilatar a proposta aristotélica sobre a natureza do saber, o que diríamos hoje o saber científico. Trata-se, pois, de um estudo do que é, para o Estagirita, a epistêmê. Em um português castiço, por vezes barroco, mas sempre elegante e preciso, Porchat buscou mostrar, primeiramente, que Aristóteles tomou como paradigma do saber científico o conhecimento matemático. Daqui se compreende imediatamente a sua natureza axiomática, ou quase: trata-se de um saber demonstrativo, estruturado em deduçóes e demonstraçóes, como sói ocorrer nas ciências matemáticas. De fato, a matemática estava em um momento privilegiado na época de Aristóteles; os estudos que estavam então sendo feitos e discutidos serão em breve compilados por Euclides nos Elementos. Aristóteles tomou parte, ainda que pequena, nestas discussóes. A natureza do objeto matemático foi uma de suas preocupaçóes, e isso de um ponto de vista propriamente metafísico, mas ele também tomou partido em algumas disputas propriamente matemáticas. A doutrina das proporçóes tinha duas versóes: uma específica, de natureza propriamente aritmética, retratada no livro VII dos Elementos, que opera sempre com a noção de comensurabilidade numérica. Esta é a teoria mais antiga das proporçóes, provavelmente de origem pitagórica; ao que tudo indica, a descoberta da incomensurabilidade causou um grande impacto na matemática, tendo também diretas repercussóes na teoria das proporçôes. Com efeito, Euclides nos reporta, no livro V, uma doutrina generalizada das proporçôes, que não somente é válida simultaneamente para a aritmética, a geometria, a harmonia música e todas as disciplinas matemáticas, como também, e sobretudo, é concebida de modo a ficar imune aos problemas da incomensurabilidade. Esta nova doutrina das proporçôes é o resultado dos estudos de Eudoxo - se pudermos dar fé a um escólio anônimo ao livro V. Ela é apresentada no livro $\mathrm{V}$ dos Elementos de modo geométrico (como são as provas de Euclides), mas de fato é concebida como uma doutrina generalizada das proporçôes (sinal disso é que, no livro VI, ela é aplicada especificamente à geometria). É curioso observar que Euclides não faz nenhum esforço para reduzir a doutrina aritmética das proporçóes, exposta no livro VII, aos princípios da doutrina generalizada, exposta no livro V. As duas versóes convivem sem conflitos e, muito provavelmente, foram assim reportadas dada a fidelidade de Euclides em compilar o estado do conhecimento matemático de sua época. De qualquer modo, Aristóteles tomou clara posiçáo neste debate, ao defender a doutrina generalizada das proporçôes, que ele, aliás, aplica a um domínio não matemático, o domínio dos atos justos. Mais do que isso, Aristóteles se dá ao luxo de propor correçóes à doutrina generalizada das proporçóes. Na definição V 8, Euclides escreve que a menor proporção 
contém três termos; ora, para Aristóteles, isto está errado, pois toda proporção requer pelo menos quatro termos para se estabelecer (um dos quais podendo ser repetido: $\mathrm{a}: \mathrm{b}:: \mathrm{b}: \mathrm{c})$, como declara em $E N V 6$ II3a3I-2 ${ }^{1}$.

Aristóteles, obviamente, não se limitou simplesmente a adotar a ciência matemática como paradigma do conhecimento científico sob a forma de um conhecimento axiomático. ${ }^{2}$ Ele pôde expandir este programa a todo saber e ciência justamente na medida em que constituiu por primeira vez o campo da dedução, e o fez sob a forma de uma doutrina do silogismo, o que, como todos sabemos, por muitos séculos foi vista como a teoria por excelência da inferência lógica. Tendo recusado que uma prova pudesse ser válida a título de um recorte parcial em um número infinito de premissas ou, ainda, que pudesse se fundamentar de modo circular, Aristóteles precisou dar um tratamento filosófico ao problema das premissas iniciais; daqui a noçáo de indemonstrabilidade dos princípios, mas também daqui as noçôes de por si, de universal, de premissa necessária, noçôes estas que Porchat apresenta e examina ao longo dos quatro primeiros capítulos de sua tese. Um ponto importante que Porchat examina é a separação dos gêneros e dos conhecimentos científicos que a eles correspondem, o que é uma contribuição importante e própria de Aristóteles ao debate sobre a natureza e as ordens de conhecimento. O capítulo 5 da tese de Porchat é dedicado ao estudo das definiçôes, cuja natureza é discutida nos capítulos iniciais do livro II dos Segundos Analíticos. Porchat mostra, com sua precisão e elegância costumeiras, o quanto a doutrina aristotélica das definiçôes é solidária de sua visão demonstrativa da ciência, ligando-a à temática (mais metafísica) da essência e quididade no interior do conhecimento científico, mas obviamente sendo devedora daquele padrão matemático de prova.

Este programa tem muitos restos, por assim dizer. Para nomear somente dois: um deles é a questão do conhecimento do que ocorre não necessariamente, mas nas mais das vezes, o famoso hôs epi to polu que Aristóteles procurou integrar ao seu programa de inspiração matemática, em relação ao qual Porchat cunhou a expressão de necessidade estorvada, e que, no desdobramento do conhecimento científico, em especial em sua vertente biológica, será apresentado como a necessidade hipotética. Um segundo resto é o não menos famoso problema da apreensão daqueles primeiros prin-

\footnotetext{
1 Para maiores detalhes do uso da doutrina generalizada das proporçôes, tomo a liberdade de enviar à minha tradução comentada Aristóteles - Ethica Nicomachea VI- IS Tratado da justiça, 2017.

2 Há sinais inclusive quanto ao modo de redigir textos filosóficos: com efeito, o tratado das Categorias tem um modo de redação que em muito se assemelha ao que virá a ser os Elementos de Euclides, a saber, uma primeira parte em que são listados os princípios e axiomas, sem nenhuma introdução ou explicação, que depois são usados diretamente no corpo das provas. Nas Categorias, os primeiros capítulos ( I a 4) parecem seguir esta estrutura, ao passo que, a partir do capítulo 5, vemos a aplicação do que ali foi apresentado ao conteúdo examinado. Sobre este ponto, ver em especial Paolo Fait, 20II, p. 33-50.
} 
cípios, base de toda demonstração, mas eles próprios indemonstráveis. É para a soluçáo deste problema que o último capítulo da tese de Porchat (o capítulo VI), bem como a sua conclusão são concebidos e, nas palavras do próprio Porchat, "constituem a parte crucial da tese e contêm sua contribuição mais importante para a compreensão da filosofia aristotélica” (Porchat, 2000, p. I8). Como veremos mais adiante, a solução que Porchat propóe, inovadora em seu tempo, consiste em apelar à dialética, tal como exposta nos Tópicos, para iluminar e complementar a interpretação dos Segundos Analitcos II I9, o último capítulo dos Analíticos, e não menos famoso do que a própria obra, no qual Aristóteles expóe sua visão do nous e da apreensão dos primeiros princípios, que, ao mesmo tempo, garante cientificidade rigorosa aos nossos conhecimentos e abandona de vez as pretensóes inatistas do projeto platônico de compreender todo saber como uma rememoraçáo do já sabido.

Antes, porém, de apresentar a tese de Porchat a respeito da apreensão dos primeiros princípios, gostaria de falar um pouco da publicaçáo do livro Ciência e Dialética em Aristóteles, pela editora da UNESP em 2000, na coleção Biblioteca de Filosofia, dirigida por Marilena Chauí. O livro é a tese de 1967, enfim publicada 33 anos depois de sua defesa, graças aos esforços de Marisa Lopes em digitar e editar o texto e de Ricardo Terra em convencer Porchat a publicar o livro, não sem as ameaças de praxe. Por muito tempo referência como que limitada a São Paulo, a tese ganhou dimensão nacional e pôde assim ser lida e refletida nos mais longínquos rincóes deste país. Poderia também ter sido publicada em língua internacional - a suposta língua franca que seria o inglês, ou no francês, que daria à elegância da escrita de Porchat o charme da pronúncia de uma langue d'ö̈l. Embora muita coisa tenha sido publicada até o final do século passado sobre a dialética, e em certos aspectos tenha tornado o livro de Porchat carente de uma atualização, a tese de Porchat tem uma vivacidade que a fez sobreviver a anos de reclusáo acadêmica e virou de pronto um livro para o novo século, após dormitar 33 anos na nova Skepsis das bibliotecas universitárias.

No início de 2004, a revista Analytica publicou, sob minha coordenação, um número especial de discussão do livro de Porchat. Este dossiê continha três artigos de análise da obra de Porchat: um feito por Lucas Angioni, centrado sobretudo na recuperação mais consistente da relação entre eventos e sua necessidade nos marcos da ciência aristotélica, como a morte do boi por causa de sua degola, a chamada relação per se $e_{4}$, deixada como que à sombra por Porchat em seu estudo, e que Pacius (I 4OI) assimilava à relação entre causa e efeito; um outro escrito por Francis Wolff, que justamente examinava o impacto do padrão matemático na constituição da ciência aristotélica; e um terceiro escrito por mim mesmo, dedicado ao exame do problema da aquisiçáo dos primeiros princípios. A todos estes textos Porchat escreveu uma réplica, publicada neste mesmo número. Anos mais tarde, Porchat me exprimiu, em diferentes ocasióes, o desejo de ver esse volume transformado em livro, algo similar com o que tinha ocorrido entre sua tese de 1967 e o livro de 2000. Certo, não havia passado tantos anos assim, nem a Analytica dormia escondida em algum porão da nova Skepsis; porém, haveria a contrarréplica de nossa parte, bem 
como a tréplica de Porchat, o que tornaria o dossiê ainda mais interessante. O projeto era ambicioso e o acalentamos por um bom tempo, mas os múltiplos afazeres da vida universitária, novos interesses, tudo veio a conspirar contra a consecuçáo deste projeto, que terminou adormecido por todos estes anos, não fosse esta ocasiáo para o retirar de seu sono profundo. Hoje lamento muito não ter insistido mais para a realização deste projeto. Havia já no dossiê publicado algo que fazia jus não somente às ideias de Porchat, mas sobretudo à postura Porchat, esta atitude de suscitar debates, animar controvérsias, o nunca se satisfazer com o dito de alguma autoridade, por mais bem estabelecida que estivesse no palmarès das prosápias acadêmicas. Esta edição abortada teria certamente ilustrado, mais uma vez a elegância de sua atitude acadêmica, acompanhada de sua costumeira generosidade.

Mas voltemos à obra propriamente dita. Como disse, vou concentrar-me no problema da aquisiçáo dos primeiros princípios, problema que o próprio Porchat considerava como sua contribuição mais relevante neste estudo. Procederei do seguinte modo: apresentarei $<$ a primeiro o que me parece ser a tese de Porchat; depois, analisarei $<\mathrm{b}>$ algumas passagens menos favoráveis à leitura de Porchat; $<\mathrm{c}>\mathrm{em}$ um terceiro momento, vou relatar sucintamente a réplica que me fez, para entáo, em um quarto e último momento $<\mathrm{d}>$, fazer três breves consideraçóes sobre o tema em pauta em uma tentativa de entender o que gera o núcleo filosoficamente fecundo da presente controvérsia ${ }^{3}$.

O problema é bem conhecido. Para Aristóteles, a ciência procede por demonstraçóes; ela é definida como uma disposição demonstrativa. Toda demonstração parte de princípios que, eles próprios, não podem ser demonstrados, sob pena de se ir ao infinito, ao se exigir sempre demonstração do que serviu de base à demonstração. É preciso então parar em algum momento; Aristóteles estabelece a parada mediante a existência de princípios a título de proposiçóes imediatas e primeiras, indemonstráveis, a partir das quais as ciências partem para a demonstração das propriedades dos gêneros próprios de que se ocupam. ${ }^{4} \mathrm{~A}$ apreensão dos primeiros princípios é atribuída ao voũs, inteligência. Náo há deles ciência em sentido estrito, mas a inteligência, que é sempre verdadeira, integra a sabedoria, sophia (da qual a outra parte é a ciência em sentido estrito, غ̇ंı $\sigma \tau \eta ́ \mu \eta)$, na medida em que fornece o material

3 Para $<\mathrm{a}>\mathrm{e}<\mathrm{b}>$, vou repetir em grande parte o que escrevi em Dialética, Indução e Inteligência na Aquisição dos Primeiros Princípios, o texto que escrevi para o dossiê "Sobre Ciência e Dialética em Aristóteles", publicado na Analytica vol. 8 n. I 2004, p. 27-4I. Quem leu este texto pode simplesmente pular estas duas partes.

4 Coerente com sua preocupação focada nos dois primeiros sentidos de per se, Porchat não se preocupa em examinar a primeira parte do segundo livro dos Segundos Analíticos, nos quais, inicialmente de modo aporético, Aristóteles investiga se é possível demonstrar as definiçóes; a solução afirmativa apresentada diz respeito a somente certas definiçóes, as que envolvem eventos em que o termo médio — ou causa do ocorrido - é exterior ao objeto mesmo de definição (como, no exemplo do trovão, ser ele o barulho causado nas nuvens pela extinção do fogo). 
verdadeiro, necessário e por si sobre o qual se erige a ciência propriamente dita.

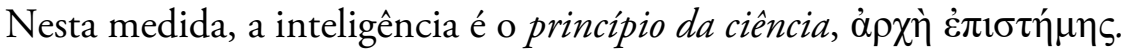

Como, porém, adquirimos estes princípios, visto que Aristóteles recusa o inatismo? Uma resposta poderia ser que intuimos estes princípios, desde que algo nos seja previamente dado na sensação. Alguns intérpretes adotaram esta saída, procurando mesmo consagrá-la na própria tradução de voũ s por intuição. No entanto, a resposta de Aristóteles parece ser mais complexa. É necessária a operação prévia da faculdade sensitiva, que pertence a todos os animais, graças à qual nos é dada, por uma certa afecção, a forma sensível do objeto percebido. Por meio da sensaçáo e de outras operaçôes a ela ligadas, como a memória, adquirimos os universais e, similarmente, os princípios (a formação de conceitos e a apreensão de princípios estão intimamente conectadas, embora Aristóteles náo tenha elucidado esta conexáo). Por que então já não chamar o voũ s diretamente de intuiçâo e dar por resolvida a tese aristotélica? Porque Aristóteles afirma que a sensação nos instila os universais (e, similarmente, os princípios) por meio da غ̇ं $\alpha \gamma \omega \gamma \eta ́$. Ora, a غ̇ं $\alpha \gamma \omega \gamma \eta ́$ é definida em Top. I I2 como o alcançar os universais a partir dos particulares, e isto parece designar claramente não a intuição, mas a indução.

Poder-se-ia dizer que, ao jungir indução e intuição, tudo o que Aristóteles estaria fazendo seria reconhecer a fraqueza interna da indução, que não tem como passar de $a_{1}, a_{2}, a_{3} \ldots$ a $A$ a náo ser por conta do salto que lhe forneceria justamente a intuição, o que faria com que os princípios fossem adquiridos por uma indução robustecida, no momento decisivo, de intuição. Pode-se igualmente lamentar que Aristóteles tenha meramente acoplado estas duas noçóes de naturezas bem distintas, sem ter conseguido ou mesmo desejado decidir entre elas. No entanto, contra estas duas explicaçôes deve-se assinalar, na esteira de Barnes, que voũs designa o estado ou disposição que apreende os princípios; غ̇ं $\alpha \gamma \omega \gamma \eta ́$, o meio ou método pelo qual os apreendemos ${ }^{5}$. Intuição e indução não respondem à mesma questão, tampouco estão em conflito. As soluções assinaladas acima estão baseadas em um falso dilema. Porchat obvia tudo isso com sua clareza costumeira:

Ora, um mínimo de reflexão é suficiente para compreender que toda a dificuldade do problema do conhecimento dos princípios reside na relação a estabelecer entre o método indutivo <...> e a função cognitiva da inteligência, cuja competência exclusiva ele reconheceu, no último capítulo dos Segundos Analíticos, nas mesmas linhas que seguem seu pronunciamento sobre o valor heurístico da indução. (Porchat, 2000, p. 353)

Feito o diagnóstico com a precisão de sempre, que receita dá para resolvê-lo? Porchat volta-se a um texto "cuja contribuição para a solução das dificuldades com

${ }^{5}$ Cf. J. Barnes, 1993, p. 259-271. 
que nos defrontamos haverá de revelar-se decisiva" (Ibid., p. 356). Trata-se de Tópi$\cos$ I 2, capítulo no qual Aristóteles argumenta em favor da dialética como podendo discorrer sobre os primeiros princípios ao converter as opinióes aceitas, $\tau \grave{\alpha}$ है $v \delta o \xi \alpha$, em premissas de seus raciocínios (Porchat traduz $\tau \grave{\alpha}$ Ěv $\delta o \xi \alpha$ por opinióes aceitas). A dialética vê-se assim incumbida da elevada tarefa de nos levar à apreensão das verdades primeiras. Como a dialética pode discorrer sobre tudo, apoiando-se nas opiniốes aceitas, nesta medida ela pode contribuir para a aquisição de todos os princípios. Porchat não diz que ela fornece os princípios; seria demasiado exigir isso dela. A dialética funciona como "uma propedêutica à ciência, um método preliminar de argumentação, contraditório e crítico, que laboriosamente 'prepara o terreno' para uma visáo posterior cujo advento ele terá tornado possível” (Ibid., p. 372). De um modo elegante, mas críptico, Porchat escreve que "o conhecimento dos princípios emerge da argumentação dialética sem ser engendrado por ela" (Ibid.). O dialético arruma a cama na qual, porém, não há de deitar: "uma vez encontrados os princípios, não mais se move na dialética, mas tem instaurada a ciência, cujos princípios agora possui" (Ibid., p. 373). Assim, o problema da indução — intuição terá solução se conciliarmos não dois, mas três termos: "dialética, induçáo e inteligência dos princípios" (Ibid., p. 384).

Isto é feito em dois passos. Inicialmente, unem-se dialética e indução: "dizendo respeito, portanto, ao momento heurístico e ascendente do conhecimento, $a$ indução é de natureza dialética" (Ibid., p. 385). E a indução é dialética porque:

se exprime $<\ldots>$ sob a forma de opinióes ( $\delta$ ó $\xi \alpha \imath$ ) que, formuladas como proposiçóes aceitas ( $\left.\tilde{\varepsilon}^{\prime} v \delta \mathrm{o} \xi \alpha\right)$ onde se traduz o resultado das observaçôes que se fizeram, são objeto de um tratamento dialético que as toma como ponto de partida para pô-las à prova e utilizá-las criticamente." (Ibid., p. 386)

Porchat fala assim do "método dialético-indutivo" (Ibid. p. 387, 389 e 407), consagrando esta uniâo. Resta, porém, conciliar a indução dialética com a intuição, ou melhor, com a inteligência. Isto é feito no segundo passo. Novamente é feito apelo a Top. I 2:

Ora, a aporia que tão grave nos parecia ver-se-á facilmente resolvida se estabelecermos um paralelo entre o último capítulo dos Analíticos e a passagem dos Tópicos que nos mostrou a utilidade da dialética como propedêutica ao conhecimento científico. Com efeito, Aristóteles passa, nos Segundos Analíti$\cos$, da indução à inteligência do mesmo modo como, nos Tópicos, faz surgir a visão da verdade a partir da prática da argumentação contraditória e crítica que caracteriza o método diaporemático, faz emergir da prática dialética o conhecimento dos princípios. (Ibid., 387, grifos do autor)

Resolve-se a aporia, ou antes ela se dissolve. O método dialético-indutivo cede o lugar (Ibid., p. 390) a uma intuição plena, que ele não engendrou, mas ajudou a 
fazer emergir. Esta intuição plena, absoluta e infalível, "não se acompanha de discurso": o discurso não se transmuda em inteligência, mas "suprime-se ante ela, uma vez cumprida a tarefa preliminar que lhe competia, a de assim preparar a sua mesma negação" (Ibid.). O dialético não só arruma a cama em que não há de deitar, ele destrói sua própria cadeira de repouso. É certo que Aristóteles insiste que a ciência

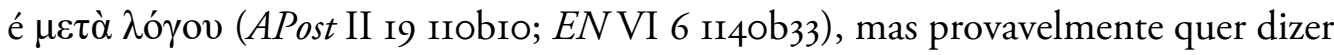
isto que se faz por justificaçóes ${ }^{6}$, isto é, com apoio em deduçóes; por contraste, a inteligência é apreensáo direta, sem precisar demonstrar o que apreende, embora redunde em discursos, pois apreender a quididade implica poder exprimi-la em uma proposição. O ponto decisivo, porém, é que Porchat se sente então autorizado a defender sua perspectiva otimista, pois, graças à dialética, "o homem habita os domínios da verdade”. Àquele que desconfiaria que a ciência acabou de eivar-se por conta deste contato com a dialética, Porchat replica que:

não vê Aristóteles contradição alguma entre esse caráter absolutamente primeiro dos princípios e o fato de apreenderem-se eles graças a uma investigação dialética que descreve como metodologicamente capaz de até eles levarnos; nem vê qualquer dificuldade em fazer emergir o conhecimento dessas proposiçóes absoluta e infalivelmente verdadeiras a partir do uso de um método cujo ponto de partida são, tão-somente, as opinióes, a opiniáo da maioria ou, ainda, a opiniáo dos sábios, de todos ou apenas de alguns, embora não se confundam opinião e verdade (já que a opinião comporta a falsidade e concerne igualmente ao verdadeiro e ao falso), embora baste ao raciocínio dialético que algo pareça verdadeiro, ainda que não o seja. (Ibid., p. 357-358)

Voltemos nossa atenção ao texto que possibilitou este convívio tão salutar entre dialética e ciência, a despeito do fosso que inevitavelmente as separa. Trata-se do curto capítulo de Tópicos I 2 Iora25-b4, que versa sobre a utilidade do próprio tratado. Este texto foi visto por muitos comentadores como uma expressa declaraçáo da parte de Aristóteles que a dialética leva à ciência. As divergências dizem respeito ao modo como leva. Porchat adotou uma versão moderada: a dialética não engendra, mas faz emergir a ciência, ela permite a eclosão desta visão intuitiva diante da qual se suprime. Forneço a seguir a traduçáo do próprio Porchat (Ibid. p. 356); introduzi sete marcas para facilitar minhas referências posteriores:

Em seguida ao que foi dito, deve dizer-se para quantas e quais coisas é útil este tratado. Ele o é para três coisas: <i > para exercício, <ii> para os encontros casuais, <iii> para as ciências filosóficas. Que é útil para exercício é manifesto

6 Como na tradução de Barnes: "all understanding involves an account”. 
a partir do que já foi dito; com efeito, possuindo um método, poderemos mais facilmente argumentar sobre o problema proposto. Para os encontros casuais, porque, tendo inventariado as opinióes da maioria dos homens, por-nos-emos em relação com eles, apoiados, não em pontos de vista que lhes são estranhos, mas nos seus próprios, fazendo mudar o que não nos pareçam dizer corretamente. <iv > Para as ciências filosóficas, porque, sendo capazes de percorrer as aporias em ambos os sentidos, perceberemos mais facilmente, em cada caso, o verdadeiro e o falso; <v> também no que concerne às primeiras dentre as proposiçóes que respeitam a cada ciência. De fato, é impossível, a partir dos princípios apropriados à ciência em questão, dizer algo sobre eles mesmos, uma vez que os princípios são primeiros dentre todas as proposiçóes; mas é por meio das proposiçóes aceitas a respeito de cada ponto que é necessário discorrer sobre eles. <vi $>$ Ora, esta é a tarefa própria, ou mais apropriada, à dialética, pois, <vii > de natureza perquiridora, ela $<$ viii $>$ possui o caminho que leva aos princípios de todas as doutrinas científicas.

Os pontos $<\mathrm{i}>\mathrm{e}<\mathrm{ii}>$ não nos interessam aqui, podendo ser ignorados. $\mathrm{O}$ ponto $<$ iii > nos coloca já no meio da batalha. Por ciências filosóficas deve-se entender sim-

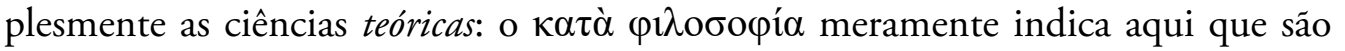
disciplinas científicas ou demonstrativas e não qualquer tipo de saber ${ }^{7}$. $\mathrm{Na}$ tradução de Porchat, o ponto <iii $>$ é explicado em $<$ iv $>$ e $\langle$ v $>$; em $\langle$ iv $>$, vê-se que tem um interesse pelas dificuldades, pois o exame destas auxilia à solução das aporia, ao nos fazer mais bem compreender o que está em jogo, mas isto é neutro em relação à aquisição dos princípios; em $\langle\mathrm{v}\rangle$, no entanto, vê-se que a dialética é também útil no tocante aos primeiros princípios de cada ciência. Se ela pode ser útil aos primeiros princípios de cada ciência, parece sensato estender seu uso igualmente aos primeiros princípios de todas as ciências, isto é, não somente àqueles a partir dos quais deduzem, mas também àqueles com os quais deduzem, como o princípio de não contradiçáo. O ponto <vi> parece dizer isso, o que corresponde ao que depois será feito no livro $\Gamma$ da Metafísica. Por fim, resta saber se a incumbência de $<\mathrm{v}>$, que, convém assinalar, é decisiva para a possibilidade de toda ciência, é uma tarefa exclusiva da dialética ou pode ser partilhada por outra faculdade — no caso, a inteligência, à qual caberia ver o que insinua a dialética.

Pode este texto certificar táo elevada tarefa à dialética? Para abrir minhas cartas de uma vez, não estou tão seguro. A posição de Porchat é bastante cautelosa: a dialética não engendra, mas faz emergir os princípios. Temo, contudo, que nem isso faz, ou muito pouco. Minha posição não é nenhuma novidade ${ }^{8}$. O ponto $<$ v $>$ diz

7 A este respeito, ver Aubenque, 1967, p. 9-3I.

8 Recentemente, Robin Smith sustentou que Top. I 2 não diz nada a propósito da dialética ser o método de descoberta dos primeiros princípios de cada ciência (I993, p. 335-358). No artigo, R. Smith concluía que "Aristotle is asserting, not that dialectic includes a method for establishing objective starting points in the sciences, but that it has some use in connection with any examination of the common principles" (Ibid., p. 354), em direta ligação com sua tese que, em $<\mathrm{v}>$, "the subject is the common principles, not the proper principles of the special sciences" (Ibid., p. 352). Smith sustenta, com efeito, que este texto não serve para 
respeito aos princípios de cada ciência, e isto para mim, como transparece também na tradução de Porchat, se refere aos princípios próprios das ciências. Isto me parece

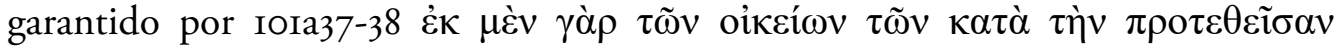
$\dot{\varepsilon} \pi 1 \sigma \tau \eta \dot{\mu \eta} v$ ả $\chi \tilde{\omega} v$, a partir dos princípios apropriados à ciência em questão. Unicamente na última linha do texto é dito que a dialética "tem a ver com os princípios

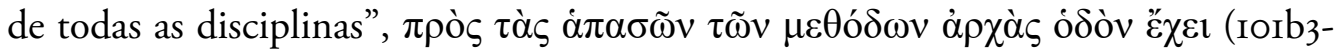
4). Esta passagem pode ser lida como se incluísse os princípios comuns, pois eles são princípios de todas as disciplinas. Ainda assim, é de se notar que a extensão aos princípios comuns só se faria, nesta leitura, após o uso da dialética relativamente aos princípios próprios. Contudo, esta não me parece ser a leitura mais natural: na

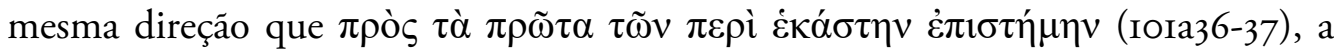
passagem parece-me somente querer dizer que, em conclusão, a dialética tem contato com os princípios <próprios> de todas as disciplinas, isto é, com os princípios primeiros de cada ciência, tomadas agora coletivamente.

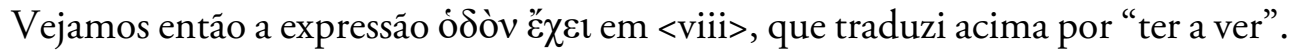
Os comentadores viam aqui a afirmaçáo quase pomposa segundo a qual a dialética "possui o caminho" aos primeiros princípios, ou, em inglês, has a road to the first principles. ${ }^{9}$ Em português, abrir caminho é uma versão discreta de ter a chave: o ponto seria que a dialética tem a chave dos princípios. Talvez, porém, a expressão

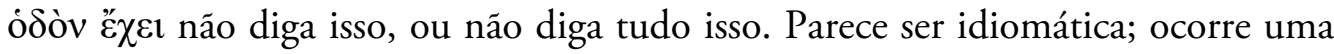
outra vez, em Met. I 4 I055a6-7, quando é dito que as diferenças quanto ao gênero

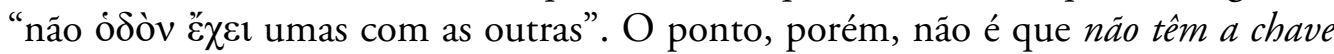
umas das outras, mas sim que não têm nada a ver umas com as outras, ou, em outros

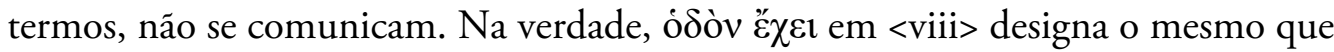

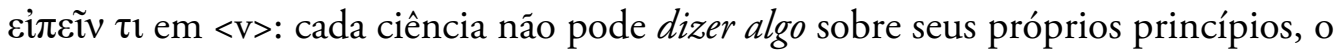
que faz a dialética, pois não possui as mesmas limitaçóes. Não se trata, contudo, de trilhar o caminho aos primeiros princípios, mas somente de poder dizer algo sobre eles - sem que se saiba ainda qual o valor desta fala. Em todo caso, parece ser bem

mostrar que a dialética pode nos servir de guia para obter os princípios de cada ciência (isto é, os princípios próprios das ciências, limitados a cada gênero) porque, em $\langle\mathrm{v}\rangle$, nada disso está sendo referido, já que, para ele, $<v>$ diz respeito unicamente aos princípios comuns das ciências (como o princípio de não-contradição). Não penso que seja assim; aliás, penso que seja exatamente o oposto, como foi defendido por J. Brunschwig, 2000, p. I07-I30. Posteriormente, em sua edição dos Tópicos I e VIII (1997), Robin Smith abandonou sua tese que se tratava somente de princípios comuns, mas manteve a mais importante, a saber, que poder dizer alguma coisa sobre os primeiros princípios não é equivalente a estabelecê-los: "Aristotle does not say merely that the starting-points cannot be demonstrated, but that by means of demonstration we cannot say anything about them. The alternative to having nothing to say is having something to say, and that could fall short of establishing" (p. 54).

9 T. Irwin assim traduz a passagem: "and this is proper to dialectic alone, or to it more than to anything else; for since it examines, it has a road towards the first principles of all disciplines" (1988, p. 37). Irwin havia já traduzido $<\mathrm{v}>$ por "and it is useful for <finding $>$ the first principles of each Science", quando o texto diz somente que é útil "também no que concerne às primeiras dentre as proposiçóes que respeitam a cada ciência”. A dialética pode ser útil sem necessariamente descobrir os primeiros princípios. 
mais modesto do que uma estrada pavimentada e bem sinalizada para a descoberta dos princípios.

O ponto mais importante, contudo, se encontra na passagem de $<\mathrm{iv}>\mathrm{a}<\mathrm{v}>$. $\mathrm{Na}$ tradução de Porchat, há uma clara continuidade; no texto grego, porém, há um forte indício que $<\mathrm{v}>$ foi acrescentado como se fosse um afterthought. Com efeito,

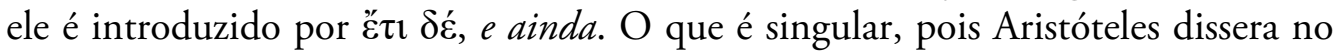
início que o tratado era útil para três coisas, mas acabou listando quatro. A tentação é grande de arrumar o texto unindo as duas últimas, mas talvez valha a pena resistir à tentação. Jacques Brunschwig deu boas razóes para tanto: (I) <iv> ilustra de modo preciso a terceira utilidade do tratado, mas esta apresentação inicial náo faz nenhuma referência a um uso relativamente aos primeiros princípios, objeto de $\langle\mathrm{v}\rangle$; (2) <iv> e <v> são separados por ětı $\delta \varepsilon$, que normalmente assinala a introdução de um ponto novo; (3) a descoberta do verdadeiro e do falso em $<$ iv $>$ é geral, pois pode ocorrer em todos os níveis, enquanto o papel da dialética em $<v>$ é muito especial; (4) o uso da dialética em <iv> não é indispensável, ${ }^{10}$ enquanto seu uso parece indispensável para a tarefa descrita em $\langle\mathrm{v}\rangle$. Tomados isoladamente, talvez nenhum seja forte o suficiente, mas, em conjunto, parece-me serem muito convincentes. Tudo se passa como se Aristóteles tivesse acrescentado, lateralmente, este outro uso; se for isso, temos aqui mais um indício que o papel da dialética não parece carregado de táo peregrina incumbência, a de encontrar os primeiros princípios, tampouco mesmo a de fazê-los emergir para serem vistos pela inteligência.

Há uma passagem célebre, no entanto, que vai ao encontro do sentimento que a dialética não só está envolvida com os primeiros princípios de cada ciência, mas sobretudo diz respeito aos princípios comuns de todas as ciências. Refiro-me a $\Gamma 4 \mathrm{da}$ Metafísica, passagem na qual Aristóteles se propóe a refutar aqueles que negam o princípio de não contradição. Apresentei em outro lugar o que me parece ser a estrutura de tal refutaçáo, ${ }^{11}$ quero aqui tão-somente aludir a alguns de seus traços. Em primeiro lugar, Aristóteles oscila quando se refere ao que está fazendo. Ele ora diz que se trata de uma demonstração, ora declara que não é possível uma demonstração, mas somente uma refutação, Ě̉ $\varepsilon \gamma \chi 0 \varsigma$. É bem verdade que a refutação faz parte das estratégias dialéticas, mas surpreende o fato de Aristóteles não afirmar nunca, em $\Gamma_{4}$, que está procedendo dialeticamente. Talvez o seu silêncio seja proposital, como já assinalou Brunschwig ${ }^{12}$ : em todo caso, ele é significativo. Porém, mais fecundo que

\footnotetext{
${ }^{10}$ Enrico Berti, em um artigo no qual pretendia mostrar que a filosofia primeira é concebida por Aristóteles "comme une recherche argumentée dialectiquement" (1997, p. 382), insistiu sobre o papel da dialética de resolver as dificuldades. Este papel diz respeito, porém, ao ponto <iv>, enquanto a discussão gira em torno de $\langle\mathrm{v}\rangle$. Para $\langle\mathrm{v}\rangle$, Berti precisa introduzir um segundo uso da dialética, a saber, a refutação das opiniốes opostas e a resoluçáo "des objections faites par les sophistes au moyen de la distinction des diverses significations de l'être" (Ibid., p. 396). Independentemente da introdução dos sofistas neste segundo uso, resta que este procedimento náo leva à descoberta dos princípios, mas procede à refutaçáo da opinião de outros com base nos princípios.

${ }^{11}$ Em Zingano, 2003.

${ }^{12}$ Brunschwig, 2000, p. I25: "et pourtant, Aristote dit غ่̇ $\varepsilon \gamma \kappa \tau \iota \kappa \tilde{\omega} \varsigma$, il ne dit pas $\delta \iota \alpha \lambda \varepsilon \tau \iota \kappa \tilde{\omega} \varsigma$. Est-ce par hasard ?”
} 
este indício é a observação que, o que quer que Aristóteles esteja fazendo, não se trata de encontrar um caminho para o princípio de não-contradição, mas de barrar a via a quem se nega a reconhecê-lo. A lição é eminentemente negativa: aparentemente, a aquisição do princípio se faz alhures, sua negação unicamente é que requer o uso da dialética, se tanto, a fim de reduzir quem o nega ao silêncio das plantas.

Talvez, porém, Top. I 2 não esteja falando nada sobre princípios comuns, de sorte que a lição negativa de Met. $\Gamma$ náo o afetaria. No entanto, uma outra passagem nos fornece a mesma lição, desta vez a respeito dos princípios próprios de cada ciência. Em Physica I 2-3, Aristóteles visa a refutar Parmênides e Melisso, que negavam o movimento. Negar o movimento redunda em aniquilar a própria física, e "não há mais argumentação contra quem suprime seus princípios - mas tal argumentaçáo compete ou a uma outra ciência ou a uma ciência comum a todas" (I 2 I85aI-3) ) $^{13}$. Estamos agora claramente às voltas com os princípios próprios das ciências, no caso, da física. Como se sabe, tal tarefa náo incumbe a uma outra ciência, pois isto seria uma metabasis eis allo genos. Caberá, se é que cabe, a uma ciência comum a todas. Pode-se pensar que tal ciência seja a metafísica ou ciência do ser enquanto tal, mas isso é pouco provável. Há fortes indícios, ao longo da Física, que nos fazem suspeitar que Aristóteles não dispunha ainda, ao escrevê-la, do que veio a ser, mais tarde, a sua doutrina da substância como ser primeiro, que finalmente lhe permite uma ontologia fora do diapasão platônico. Mesmo, porém, que já dispusesse dela, não é claro em que sentido a ciência do ser enquanto tal forneceria à física uma prova do movimento, ou se, partindo da existência de substâncias sensíveis, isto é, das substâncias passíveis de movimento, buscaria então os traços gerais da substancialidade, que se mostrarão compatíveis com a existência de uma substância de outra natureza. É mais provável, assim, que esta ciência comum a todas faça referência justamente à dialética, como é dito nos Segundos Analíticos I II, pois, por ser perquiridora, não conhece os entraves das ciências propriamente ditas. A dialética é assim o sucedâneo das ciências quando se discute a respeito dos primeiros princípios. Nos Segundos Analíticos I II, o campo da dialética se alarga até os princípios comuns (o princípio de não contradição é expressamente mencionado), mas o que interessa agora é ver o que ela pode fazer no tocante aos princípios próprios, em função da negação do movimento pelos eleatas.

O que ocorre em Física I 2-3 parece-me muito similar ao que ocorreu em G 4 da Metafísica ${ }^{14}$. Segundo Aristóteles, os argumentos de Parmênides e Melisso são erísticos, assumem premissas falsas e são inconcludentes, com o agravante de os de Melisso serem vulgares e desprovidos de dificuldade. Mesmo assim, Aristóteles dispóe-

\footnotetext{
${ }^{13}$ Cito a tradução de Angioni, 2002, ligeiramente modificada.

${ }^{14} \mathrm{O}$ próprio Aristóteles adverte a esta relação: em $M e t$. $\Gamma$ 4, a negação do princípio de não contradição é atribuída a Heráclito; em Física I 2, Heráclito é mencionado duas vezes: em I85a7, o argumento heraclíteo é dito ser erístico, concebido para mera discussão, assim como o dos eleatas; em I85bı-25 o mesmo destino é dado aos dois argumentos, a saber, que tudo é e não é, "e o discurso será não a respeito dos entes serem um só, mas a respeito de serem nada".
} 
se a discuti-los, pois, como lhes ocorre de enunciar problemas atinentes à física, "por certo cai bem discutir um pouco a respeito dessas coisas, pois tal exame comporta

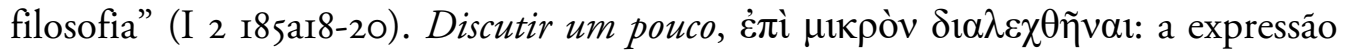
não parece augurar grandes descobertas, mas rápidas - e eventualmente ríspidas correções. A expressão final, pois tal exame comporta filosofia, não é clara: talvez se

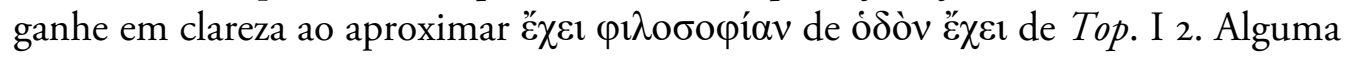
coisa se aprende de útil, mas não convém depositar muitas esperanças na discussão. Seguem então, em I 3, os argumentos de Aristóteles contra Melisso e, principalmente, contra Parmênides. Não quero examiná-los aqui; basta-me observar o seguinte. Aristóteles repete em I 3 o que dissera em I 2: as premissas são falsas e o argumentos não são válidos. Em tal situação, o melhor é ir para casa. No entanto, ao refutá-los, Aristóteles é levado a fazer alguns esclarecimentos, tais como: dois itens podem ser distintos não por extensão, mas por intensão, "o que Parmênides de modo algum considerou" (3 I86a30-33); o acidente é dito de um certo sujeito, que é distinto dele (3 I86a34-bi); o acidente é um item que pode ou não ser atribuído a um item em cuja definição se encontra aquilo de que é acidente (3 I86bı-20), ou ainda: a definição do todo não se encontra na definição daquilo que está imanente ao seu enunciado definitório (3 I86b24-25). Estas são as liçóes de casa, por assim dizer, que se ganha ao entrar em tal discussão.

Convém observar, en passant, que tais liçóes não dizem respeito a problemas da

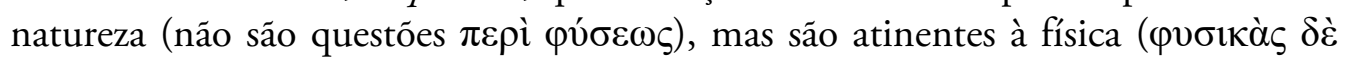
$\grave{\alpha} \pi$ opías, 2 I85ar8). Isto não deixa de ser surpreendente, pois, quando as consideramos em bloco, correspondem a questóes que são tratadas nos livros centrais da $\mathrm{Me}$ tafísica, em particular no livro $Z$, isto é, o que se pode chamar de ontologia ou metafísica aristotélica. Penso que este detalhe é mais um sinal do caráter juvenil da Física de Aristóteles. Ao que tudo indica, ele a escreveu quando, de um lado, ainda não possuía propriamente estabelecida a sua metafísica ou doutrina da substância, mas, de outro, claramente se situava já fora do diapasáo platônico (a tese inaugural do aristotelismo, o ser se diz de muitos modos, é introduzida em 2 I85a2I e repetida em 3 I86a25). Não é, porém, tarefa fácil discernir com um mínimo de precisão a que etapa pertence à Física, e mesmo se pode objetar que é irrelevante, pois tudo isso provém antes de uma superposição inevitável entre física e metafísica, não necessitando de nenhuma tese genética para sua explicaçáo. Resta, contudo, que as liçóes obtidas neste intermezzo dialético estáo por certo em torno do problema dos princípios, mas não se dirigem a eles nem os fazem emergir: seu interesse é, como no caso do princípio de não contradição, silenciar certos opositores lembrando teses básicas a respeito da enunciação e da argumentação.

Como, então, são apreendidos os primeiros princípios? Aristóteles assim escreve em 2 I85aI2-I4: "para nós, esteja estabelecido que as coisas que são por natureza, ou todas elas ou algumas, são suscetíveis de movimento: isto é evidente com base na

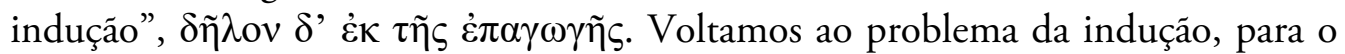
qual a dialética não parece servir de remédio. O mesmo ocorre no capítulo II I9 dos 
Segundos Analiticos: inteligência e indução são mencionadas em estreita conexão, mas não há menção alguma de um papel da dialética a propósito da aquisição dos primeiros princípios. O que náo quer dizer que seja inútil. Em <vii> é lembrado que

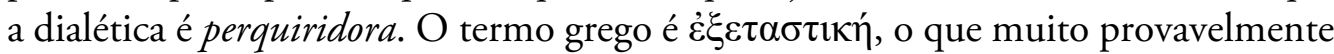
faz menção à célebre passagem da Apologia na qual Sócrates alude ao seu comportamento dialético ${ }^{15}$. Ora, seu comportamento era negativo: Sócrates mostrava que, embora nada soubesse, pelo menos sabia que nada sabia, enquanto seus interlocutores pensavam que sabiam algo, quando na verdade nada sabiam. Perquiridos por Sócrates, não podiam mais esconder a própria ignorância. Trata-se de silenciar, de solapar, não de construir ou avançar. $\mathrm{Na}$ expressão de Brunschwig, "il faut donc se représenter la "voie dialectique vers les principes » comme jonchée de cadavres"16.

Nesta perspectiva negativa, ainda que não pessimista, o ponto <vi $>$ perde seu caráter enigmático: ora, esta é a tarefa própria, ou mais apropriada, à dialética. Podese perguntar se o que se quer realçar é a tarefa mais própria em comparação a outras tarefas da dialética ou se é a tarefa mais própria da dialética em relação a outras disciplinas. Deve-se preferir a segunda possibilidade, em função da menção de sua característica perquiridora. ${ }^{17}$ Neste caso, pela restrição ou mais apropriada, Aristóteles como que se reserva a possibilidade de um outro acesso - que não pode ser outro senão a inteligência. Porém, o texto se torna enigmático, pois diz então que, comparado ao outro meio, a inteligência, a dialética é a mais apropriada para a aquisição dos princípios, embora só os faça emergir, sem engendrá-los, suprimindo-se ante ela, a inteligência, que é a visão dos princípios. Por que mais apropriada, se tem uma função unicamente propedêutica? Se, porém, considerarmos a função perquiridora em sua natureza negativa, compreende-se melhor por que esta tarefa lhe seja própria ou mais apropriada. É próprio da perquirição socrática, ou lhe é mais apropriado, a destruição sistemática das crenças falsas de seus interlocutores.

Em suma, a despeito da elegância e da fecundidade da argumentação de Porchat, permaneço cético quanto à possibilidade de usar Top. I 2 para a função decisiva que ele lhe atribuiu de elucidar a relação entre indução e intuição (ou inteligência) na aquisição dos primeiros princípios mediante a intervenção da dialética. A dialética tem sua utilidade, a de pôr tudo à prova, mas, no tocante à aquisição dos princípios, seu papel náo parece poder responder ao que lhe é requerido, embora possa sempre dizer algo a respeito dos princípios.

\footnotetext{
$15 \mathrm{O}$ ponto foi acentuado por vários comentadores; convém assinalar, contudo, o uso corrente do termo pelo próprio Aristóteles (por exemplo em EE I 3 I2I5a3-7), que declara, no início da Retórica, que "todos os homens

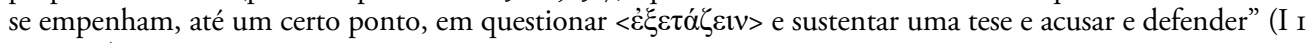
I354a4-6).

${ }^{16}$ Brunschwig, 2000, p. 124 .

${ }^{17}$ Ver o comentário de Brunschwig, p. II7 de sua edição Topiques $I$ - IV, 1967.
} 
Citei largamente meu próprio artigo para tornar mais compreensível a réplica que Porchat fez a ele. Sucintamente, Porchat, com a elegância de sempre, e não sem uma pitada de bom humor, defendeu fundamentalmente ${ }^{18}$ os seguintes quatro pontos. (I) Para ele, a expressão trilhar o caminho e ter a chave são metáforas que têm, nas mais das vezes, usos diferentes, ainda que possam, eventualmente, ser intercambiáveis. Por possuir ou trilhar o caminho, Porchat náo visa a prever uma estrada pavimentada, bem sinalizada e sem dificuldades; ao contrário, ele insiste que, ao longo de seu livro, buscou marcar quáo difícil a busca dos primeiros princípios pode ser. Como assinala, sua ideia de um uso dialético propedêutico em nada trazia "a garantia infalível de um uso absoluto" (I50). Daí mesmo o estatuto de discussão e, consequentemente, de falibilidade em seu uso. (2) Em segundo lugar, Porchat não vê soluçáo de continuidade entre (iv) e (v) quanto às tarefas da dialética no tocante às disciplinas dialéticas. Para ele, ao contrário, se trata de uma terceira funçáo que naturalmente se desdobra em dois momentos: a percepção do verdadeiro e do falso, de um lado, e a ida aos

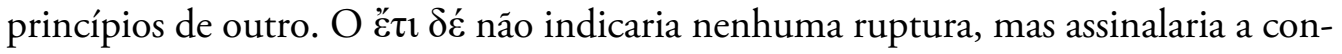
tinuidade das tarefas filosóficas da dialética. Por esta mesma razão, (v) náo pode ser uma quarta função da dialética, acrescentada a título de afterthought, mas se insere em "clara continuidade" ao papel de (iv), ambos desdobrando a terceira função da dialética. Ainda, (3) Porchat reafirma sua posição segundo a qual a inteligência, ou intuição (voũs), tem a visão dos princípios, mas esse ver requer uma preparação do terreno, o que é feito de modo propedêutico pela dialética. Dialética e intuição funcionam, assim, de modo complementar. Por fim, (4) sua leitura de Met. $\Gamma 4$ e Física I 2-3 faz com que dê um papel bem mais consequente à dialética no tocante à apreensão dos princípios do que eu deixei ver e, mesmo que concedesse senáo toda, pelo parte de minha leitura, mesmo assim Porchat reivindica uma série de outros textos em que à dialética está emprestado aquele papel propedêutico que procurou demonstrar estar teoricamente delineado em Tópicos I 2.

Porchat termina sua réplica retomando minha expressão de ceticismo quanto ao alto papel atribuído à dialética, para confessar que sabe muito bem, por experiência própria, quão difícil é convencer um cético. Somos de mesma opinião neste ponto e estou seguro que ele concordaria que o ponto não é de convencimento, mas de entender por que as posiçóes tendem a se opor do modo como nós dois as apresentamos. Por isso, vou concluir minha fala mencionando três pontos de hermenêutica

${ }^{18}$ Há uma série de outros pontos, que têm, porém, uma função menor para a réplica de Porchat. Um deles é a função refutativa ou exetastikê da dialética, que pode ter um valor mais positivo do que o que lhe atribui em certas passagens - mas isso demandaria um estudo mais detalhado das passagens relevantes (mantenho, a este respeito de tais passagens, a posição adotada no artigo). Outro ainda é a inteligência, o nous, e sua funçáo proposicional (ver a nota 9, p. I57-I58). Em meu artigo, exprimi-me de modo inexato ao caracterizá-lo como discursivo, pois isso obscurece seu contraste com a função claramente discursiva da dialética. É um ponto delicado, que requer uma análise mais detalhada do que pode ser feito aqui, pois a apreensão de conceitos é dita ser uma phasis e náo ainda uma apophansis (seja uma kataphasis ou uma apophasis); no entanto, toda qüididade é exibida em um logos, que justamente é sua definição. A passagem de sua apreensão à sua expressão, porém, requer uma série de passos, nem todos explicitamente reconhecidos por Aristóteles; resta, porém, que apreender uma essência é pôr-se à busca de sua exibição em uma fórmula definicional. 
geral, sem nenhuma pretensão a convencer ninguém, nem mesmo a mim mesmo, mas de trazer clareza à natureza de uma leitura tão diversa de Aristóteles.

Antes, porém, convém sublinhar que, ao longo desta discussão, fica claro que, para nós dois, o recurso a uma intuição para fazer o salto na aquisição dos princípios é sempre insuficiente se esta não vier acompanhada de uma explicitaçáo dos trabalhos conceituais se não para adquirir, pelo menos para exprimir as essências assim apreendidas. A caça às quididades não parece poder ser feita no mundo não-discursivo e silencioso das intuiçóes; por esta razão, penso, Porchat tanto insistiu no método, para ele trabalhoso, da argumentação dialética, sempre falível e instável, mas o único trabalho da razão na elucidação argumentativa das essências adquiridas. Em minha resposta, insisti que, para retomar a expressão de Brunschwig, o trabalho da dialética era basicamente negativo, uma subida ao Himalaia que, como sabemos, está "jonchée de cadavres". Como veremos mais adiante, um trabalho de reflexão está de fato previsto no interior dos procedimentos de exibição das definiçôes das quididades apreendidas. Em alguns casos, isso se dá por meio de uma demonstração, o que é possível quando o termo médio do silogismo é causa externa do que está sendo definido, que aparece assim na conclusão; em outros, porém, é uma caça mais misteriosa, cujo desenlace supóe um trabalho de reflexão, mas que não elucida seus próprios passos e ao qual sobrevém uma apreensão necessariamente verdadeira. Todo o problema é que falar de uma induçáo-intuição parece inevitavelmente jungir cavalos com grifos, para citar o Poeta.

Disse acima que a posição de Porchat era moderada ao atribuir à dialética um papel propedêutico, mas importante no estabelecimento dos primeiros princípios. Porém, como pode ser moderada, se Aristóteles, já nos Analíticos, claramente distingue a prova dialética, que obtém persuasão e está fundada em opinióes aceitas, da prova filosófica, que procede por premissas (necessariamente) verdadeiras e angaria convicção? Afinal, o próprio Aristóteles assinala haver um fosso entre provas dialéticas, fundadas em premissas reputadas, e provas científicas, pois as primeiras, mesmo que suas proposiçóes sejam verdadeiras, as tomam como premissas de seus argumentos não por serem verdadeiras, mas com base em sua reputabilidade, ao passo que as segundas não podem senão residir no verdadeiro ${ }^{19}$ A caracterização da posição de Porchat como moderada provém não de sua leitura de Aristóteles, mas de sua posição entre as leituras que, nos anos 6o, foram oferecidas. Em primeiro lugar, é preciso ressaltar que a posição de Porchat seguia os ares de sua época. Wilpert, dez anos antes, em 1957, escreveu, a respeito da dialética em Aristóteles, que "a indução e a dialética se demarcam como o caminho da descoberta e o nous como o método da

\footnotetext{
${ }^{19}$ Ver em especial Seg. Anal. I 6 74b2I-I4; para a oposição entre argumento filosófico (ou científico) e dialético, ver Top. I I4 Iosb3O-I.
} 
intuição" ${ }^{20}$. A leitura é a mesma, a linguagem é já muito próxima. Ambos estão preocupados com a defasagem entre o método dedutivo apresentado nos Segundos Analíticos e a prática da descoberta científica, tal como é ilustrada nos tratados biológicos, como a História dos Animais, repleta de procedimentos indutivos, classificaçóes provisórias e com uma ausência conspícua de silogismos e demonstraçóes — ou, pelo menos, uma aparente ausência.

Este movimento de dialetização da filosofia aristotélica encontrou grande ressonância quando Irwin publicou em 1988 sua obra maior, Aristotle's First Principles. A estratégia de Irwin consistia em distinguir entre uma dialética ordinária e uma dialética forte, de modo que o fosso entre dialética e ciência pudesse ser superado pela última, ainda que não pela primeira. Não é muito claro o que entende por dialética forte, mas se pode dizer que a dialética forte responde a condiçóes de argumentação comuns a vários domínios científicos. Para dar um exemplo: a ética fundava as suas teses centrais com apoio em teses da metafísica e da psicologia; ora, era justamente nesta junção de três áreas que os argumentos dialéticos tinham sucesso ao serem robustecidos pelo uso simultâneo em diversas disciplinas, o que Irwin chamou de dialética forte, ainda que argumentos dialéticos ordinários fracassassem na tentativa de estabelecer isoladamente teses científicas no interior de uma dada área. É como rasgar uma folha de jornal, que é fácil; porém, se você agrupar várias folhas de jornal, é muito difícil rasgá-las. Quando ocorria aquele entrelaçamento dialético de teses de distintas áreas, a dialética saía robustecida e capaz de fundar uma disciplina científica. Uma pressuposição com que Irwin precisava contar era que, para continuar com meu exemplo, a ética não somente estava ligada, mas sobretudo dependia de outras disciplinas para o estabelecimento de suas posiçóes fundantes, a despeito da clara tentativa da parte de Aristóteles em fundar cada disciplina na independência de seu gênero relativamente aos gêneros das outras disciplinas.

Apesar desta pressuposição controversa (em particular sobre o estatuto da ética aristotélica), a tese de uma dialética capaz de fundar o discurso científico foi largamente aceita por um bom momento. Esta grelha de leitura chegou ao seu ápice quando Berti a expandiu de modo radical, fundando todas as disciplinas científicas na dialética, exceção feita, obviamente, à matemática e à lógica ou silogística. Em um livro publicado em italiano em 1989, um ano após o de Irwin (e traduzido para

\footnotetext{
${ }^{20}$ Paul Wilpert, 1956, p. 255: "sie < dialectic and induction> führen bis an die Schwelle, bereiten die Klarheit vor, die dann aber als Evidenz der Principien sich von selbst ergeben muss. Der Weg der Hinführung birgt noch nicht die Einsicht in die innere Begründung selbst. Und so scheiden sich Induktion und Dialektik als Wege des Aufspürens und der Nous als die Methode der Einsicht. <...> Episteme ist die in streng apodeiktischer Form gebotene Darstellung der Begründungszusammenhänge in der ausgebauten Wissenschaft, wie sie musterhaft die Mathematik darbietet. Dialektik aber ist der Weg der Forschung, der Prüfung des Für und Wider, die sich der induktiven Methode bedient, vom Wahrscheinlichen, noch nicht Gesicherten ausgehend"). Porchat não dá sinais de ter conhecido este texto.
} 
o português em 1998), Berti atribuiu à dialética um papel tão decisivo que esta cobria agora todas as áreas científicas, exceção feita à demonstração silogística. Buscando dar fundamento a este uso expandido, Berti viu na refutação dos que negam o princípio de não contradição "um caso de verdadeira demonstração dialética, demonstração que tem todo o caráter de necessidade próprio das demonstraçôes matemáticas e que se desdobra em um procedimento incontestavelmente dialético", a ponto mesmo de declarar que, "inclusive para os princípios mais conhecidos, Aristóteles admite uma verdadeira investigaçáo, aberta à alternativa entre o verdadeiro e o falso". ${ }^{21}$ Levada ao paroxismo, a tese da dialética partout acabava por vazar água: valeria de fato isso, a alternativa entre o falso e o verdadeiro, para um princípio como aquele segundo o qual retiradas partes iguais de partes iguais os restos são iguais? Ou ainda para o mais seguro dentre todos os princípios, o princípio de não contradição? É em relação a esta expansão generalizada — a física, a metafísica, a teologia, a biologia, todas tendo seu fundamento na dialética - que a posição de Porchat, que pleiteava uma funçáo propedêutica para a dialética, que preparava a cama para a intuição, mas nela não se deitava, aparece hoje como claramente moderada.

Em reação a esta expansão por assim dizer triunfante e sem limites da dialética, passou-se a buscar sinais que indicavam que aquele fosso detectado entre o projeto da ciência demonstrativa dos Analíticos e a prática indutiva da ciência biológica não era tão importante; ao contrário, hoje em dia se procura ver nos tratados científicos de Aristóteles uma presença cada vez maior dos procedimentos descritos nos Analíticos, inclusive na Ética Nicomaqueia, a qual, desde a célebre edição de Burnet, era vista como procedendo de modo inteiramente dialético. A busca de definição por meio de um procedimento padráo para seu estabelecimento em diferentes áreas, os sinais discretos, mas omnipresentes de uma prova rigorosa, inclusive em suas premissas necessariamente verdadeiras, para além da adoção de proposiçóes somente reputadas constituem o Graal da atualidade. Na época de Porchat, porém, aquela defasagem era percebida como irreparável do ponto de vista dos Analíticos, de modo que a ponte procurada não podia ser senão a indicação de procedimentos dialéticos para a obtenção dos primeiros princípios, os quais, uma vez adquiridos, permitiam apresentar a ciência aos moldes da demonstraçáo matemática. Quando de sua confecção, a tese de Porchat era moderada; hoje, aparece como cedendo demasiadamente às pretensóes dialéticas, já que as práticas demonstrativas descritas nos Analíticos parecem estruturar os procedimentos científicos e filosóficos de Aristóteles para além de qualquer menção à dialética.

Meu segundo ponto é o seguinte. O projeto clássico de conhecimento perdurou por muitos séculos como a proposta por excelência para se compreender a natureza da ciência e do saber. Segundo este projeto, conhecer algo é conhecer a causa desta coisa; conhecer a causa de algo consiste em dispor de certo número de proposiçóes

${ }^{21}$ Enrico Berti, 1998, p. 98 e 94, respectivamente. 
com base nas quais se pode montar uma demonstração a seu respeito em que a coisa em pauta aparece explicitada na conclusão e tornada conhecida graças às premissas que governam o argumento. Ter tal conhecimento é desnudar a coisa naquilo que ela possui de necessário e infalível. Este projeto representa uma visão grandiosa do conhecimento. Quem tem tal conhecimento como que penetra no interior das próprias coisas e de lá contempla suas causas básicas e primeiras, deduz de modo rigoroso seu comportamento e constrói um corpo de proposiçóes que permanece firme e inabalável diante do incerto e sempre cambiante domínio das meras opinióes a respeito dos acidentes das coisas.

Este projeto clássico encontrou em Aristóteles um de seus grandes pensadores. Nos Primeiros Analíticos, Aristóteles apresentou por primeira vez uma exposição das regras de inferência e argumentação sob a forma de uma teoria silogística da prova com tamanho rigor e exigência que Kant, muitos séculos mais tarde, considerou o campo da lógica como tendo sido definitivamente estabelecido por Aristóteles. Um século mais tarde muita coisa mudaria, mas, na época de Kant, seu diagnóstico era amplamente partilhado. Nos Segundos Analíticos, Aristóteles faz um exame acurado do que seria a ciência segundo esta visão grandiosa do conhecimento. Com base em definiçóes que exibem o ser de cada coisa naquilo que elas são por essência - o célebre quod quid erat esse de cada coisa -, a ciência estabelece um corpo de demonstraçóes que cobre o inteiro campo do que necessariamente é. A estrutura do mundo se desvela por inteiro nos andaimes com que são montados os silogismos demonstrativos. Muita coisa ainda fica de fora, mas estas não são senão as migalhas do mundo, os acidentes e acasos que infestam o cotidiano em que vivemos, mas que caem fora da alçada da ciência e do conhecimento, que restam impávidos e sublimes diante do ruído instável do mundo.

Um tal programa é obviamente atraente e, sobretudo, embriagante, mas não deixa de criar seus próprios problemas. Ele requer, para começar, uma capacidade de apreender o mundo na sua mais profunda intimidade. Para Platáo, nós sempre estivemos lá — ou melhor, nossas almas coabitam o mundo ideal desde sempre. Aristóteles, contudo, não dispóe de um mundo já dado em nossa alma a ser meramente rememorado pela reminiscência platônica; Aristóteles, ao contrário, precisa obtê-lo a partir dos dados que nos são fornecidos pela percepção, guardados na memória e reconhecidos nos conceitos. A tarefa é imensa. Como garantir que as definiçóes de fato exibem o que as coisas são em seu âmago? Como mostrar que a cadeia silogística de demonstraçóes científicas reverbera o mundo como o espelho reflete uma imagem? Porchat, ao estudar os Segundos Analíticos, concentrou sua atençáo no calcanhar de Aquiles deste projeto grandioso do saber. Se o conhecimento consiste em deduçóes sob forma silogística, se estas demonstrações não procedem circularmente nem podem ter um número infinito de premissas, náo haveria entáo proposiçóes que devem funcionar como premissas não demonstradas de todo conhecimento, as famosas premissas imediatas, necessárias e primeiras, mais conheci- 
das do que as conclusôes? E não seriam elas indemonstradas porque indemonstráveis? Não repousaria então o conhecimento científico, segundo esta visão grandiosa, em algo não-científico? Aristóteles, como todo bom filósofo, não escamoteou as dificuldades, mas as enfrentou abertamente: "sustentamos que nem todo conhecimento é demonstrativo; ao contrário, o conhecimento das premissas imediatas é

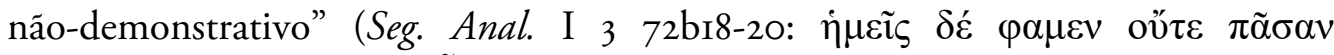

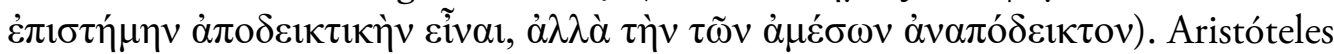
não varreu o problema para debaixo do tapete - mas como exatamente arrumou a mobília de sua sala? A intuição que fornece o intelecto, tal como exposta em Seg. Anal. II I9, pareceu a muitos, e por boas razóes, como uma solução de continuidade, que antes indicava um hiato do que fornecia a chave procurada. Porchat pôs-se diligentemente a construir uma ponte com base no que Aristóteles nos dizia da dialética, em especial nos Tópicos. A induçáo dialética náo substituía, mas estaiava a intuição intelectiva: uma bela ponte paulistana, há de se concordar.

A ponte estaiada de Porchat, com toda a sua elegância, é um recurso possível, mas certamente não o único. Uma outra solução consiste em questionar não os fundamentos, que eventualmente revelam ter pés de barro, mas o próprio projeto clássico de conhecimento, do qual eles são parte integrante. Não é mais a ponte, mas a planície toda assim interligada que então se passa a vislumbrar. Há quem o fez já na Antiguidade:

É de se supor que, aos que investigam algo, ou bem se segue a descoberta da coisa, ou a negação de sua descoberta e a admissão que é inapreensível, ou ainda o aferro à investigação. É por isso que, também entre os que investigam temas de filosofia, uns afirmaram que descobriram a verdade; outros declararam que não é possível apreendê-la, e outros continuam investigando. Creem tê-la descoberto os que são chamados propriamente de dogmáticos como Aristóteles, Epicuro, os estoicos e alguns outros —; Clitômaco, Carneades e outros acadêmicos declararam-na inapreensível; os céticos continuam investigando. (Hip. Pyr. I I-3).

Estas são, como sabemos, as frases iniciais das Hipotiposes de Sexto Empírico. E sabemos todos também o que ocorreu quando Porchat deixou de tentar estaiar a ponte dos princípios e passou a contemplar o inteiro domínio do projeto clássico de conhecimento, seus princípios e suas demonstraçóes. Ele tornou-se um cético pirrônico. Não estou dizendo que o ceticismo é a melhor resposta ao problema gerado pelo projeto clássico de conhecimento. Ele certamente não o é quando saímos fora do programa clássico, mas, no interior deste programa, o ceticismo pirrônico seguramente é a mais simpática e, por vezes, a mais generosa das respostas possíveis. O que torna tal solução muito natural para Porchat ${ }^{22}$.

\footnotetext{
${ }^{22}$ Alberto Muñoz defendeu a tese segundo a qual o método estruturalista de exame da obra por suas razóes
} internas, no caso de Porchat da obra aristotélica, o leva ao formato rudimentar das teorias dogmáticas, afir- 
O terceiro e último ponto é o que atualmente mais me intriga. Todos sabemos, e comemoramos, o renascimento dos estudos aristotélicos ocasionado pela edição que Andrônico fez de suas obras no último século da era passada, por volta de 60 aC. Pouco importa qual foi o real papel de Andrônico na retomada dos estudos aristotélicos, pois o que quero assinalar aqui é que uma mudança importante se opera neste mesmo período, argutamente identificada por Michael Frede ${ }^{23}$ : é que os filósofos entáo se transformaram em comentadores, passando a tomar os escritos dos pensadores do passado - em especial os textos de Platáo e Aristóteles - como cânones de toda reflexão filosófica. A era do comentário inicia aqui e terá seu grande momento, de um lado, quando Alexandre de Afrodísia, ainda nos limites do mundo clássico, como que dá as regras da exegese do texto (no caso, aristotélico) e, de outro, bem mais tarde, na Bizâncio do séc. XII, quando Ana Comnena estabelece seu célebre círculo de eruditos dedicados ao comentário das obras clássicas.

Cícero não parece ter tido conhecimento dos textos de Aristóteles que estavam sendo editados por Andrônico ou, pelo menos, não mostrou interesse por eles. Neste sentido, Cícero escapa à nova era dos comentadores. Ele via no orador completo a antiga figura do filósofo ateniense. Eis o que ele diz a respeito:

Se houver alguém que, ao modo de Aristóteles, puder falar em prol dos dois lados a respeito de todas as coisas e sobre todo assunto, com conhecimento das regras de Aristóteles, puder explicitar os dois discursos opostos ou, ao modo de Arcesilau e Carneades, puder argumentar contra o que quer que seja proposto e a esta doutrina puder ajuntar a experiência e o modo de falar de um orador, este seria o orador verdadeiro, o orador completo, o único orador. (De oratore III 80 $)^{24}$

Retirada a figura do orador e, consequentemente, da retórica (que foi fortemente criticada por Platão e restrita por Aristóteles ao domínio das disputas judiciais e nãofilosóficas, mas que o mundo romano quer recuperar como a verdadeira figura do filósofo), reconhecemos facilmente o procedimento antigo de investigar uma questáo examinando os dois lados para somente entáo propor a resposta. Assim fez Platão na segunda parte do Parmênides; assim fez Aristóteles, quando buscava a saída para as aporias que ele montava com o máximo cuidado. De certo modo, então, pelo menos nesta perspectiva, há uma confluência entre a dialética - a arte do orador - e o exame filosófico, de modo tal que a filosofia clássica ateniense se faria na junção destas duas tradiçóes. Não surpreende assim que a dialética, esta arte de

madas pelo recurso às decisōes noéticas, cujo caminho é preparado pela dialética, o que teria tido por consequência fazer nascer em Porchat as raízes do ceticismo pirrônico (em O Aristóteles de Porchat, p. I59-I8I). Isso é possível, desde que se permaneça preso à figura clássica do conhecimento, o que parece ser o caso de Porchat, ainda que o recurso à dialética seja um mecanismo para se não erradicar, pelo menos para fortemente atenuar eventuais tendências dogmáticas (o que, aliás, o próprio Porchat assinala em sua leitura da ciência aristotélica).

${ }^{23}$ Ver M. Frede, 2005, p. 77I-797.

${ }^{24}$ A. Wilkins, 1965 . É a passagem $4 \mathrm{~F}$ de Sharples, 2010. 
transitar nos dois lados de uma questão, de aderir sem constrangimentos à afirmação e alternadamente à negaçáo de uma mesma tese, faça parte constitutiva - e, na visão de Porchat, fundante - do discurso filosófico, entendido sob a forma geral de conhecimento científico.

Ao comentar a célebre passagem de Tópicos I 2 sobre a utilidade do referido tratado, a respeito precisamente da primeira utilidade, o puro exercício intelectual ou $\gamma u \mu v \alpha \sigma i ́ \alpha$, Alexandre escreve que Aristóteles entendia por isso ou bem o treino para defender uma posição qualquer,

Ou bem entendia por $\gamma u \mu v \alpha \sigma i ́ \alpha$ o exercício de argumentar em prol dos dois lados. Era costumeiro este tipo de argumento entre os antigos e eles conduziam a maioria de seus encontros deste modo, não com referência aos livros como agora (pois tais livros não existiam naquela época), mas, quando uma tese era proposta, pondo-se a treinar a seu propósito, eles exercitavam sua capacidade de encontrar argumentos estabelecendo e destruindo a tese por meio de proposiçôes reputadas $\left\langle\delta t^{\prime} \dot{\varepsilon} v \delta o ́ \xi \omega v>\right.$. Há livros deste tipo escritos por Aristóteles e Teofrasto contendo os argumentos para os lados opostos por meio de proposiçôes reputadas $<\delta \imath^{\prime} \dot{\varepsilon} v \delta o ́ \xi \omega v>$. $(27,8-18)^{25}$

Os últimos livros a que se refere Alexandre não são os tratados em que é exposto este modo de argumentar - estes são os Tópicos, que Alexandre está justamente a comentar; os tais livros são aqueles a que se refere Cícero, nos quais Aristóteles apresenta provas filosóficas por meio da análise dos prós e contras, ao modo dialético. Pode-se lamentar que a filosofia agora, no tempo de Alexandre, virou comentário e exegese dos textos antigos (os primeiros livros a que se refere na passagem citada). Isso não é necessariamente a morte da filosofia; afinal, Plotino concebeu sua doutrina sob a forma de uma exegese radical do platonismo, mas sua doutrina constitui uma novidade no panorama filosófico da Antiguidade. No entanto, podemos pressentir na atitude defendida por Alexandre a desilusão que tomará conta de um Pselo, quem, querendo escrever mais um comentário a Homero em pleno séc. XI, desistiu da tarefa ao ver a imensidade de tratados já escritos e a pouca utilidade de acrescentar a eles mais um, ainda que de sua autoria. Contudo, nem tudo é negativo nesse desvencilhar-se da dialética e fixar-se no comentário dos livros clássicos. A razão é que, deste modo, o caráter combativo ou agonístico em que nasceu a filosofia, e que já começava a ser atenuado, ou mesmo substituído, por Platáo e Aristóteles por um novo tipo de prova (cuja estrutura os Analíticos esboçam), é deixado de lado em proveito do estudo dos livros. Com isso, a retórica, bem como sua contraparte, a dialética, deixam a cena filosófica e não mais fazem parte constitutiva da prova filosófica, menos ainda do conhecimento científico.

\footnotetext{
${ }^{25}$ Sharples $4 \mathrm{H}$.
} 
Muito resta ainda por fazer. O livro a que se refere Alexandre em primeiro lugar são as obras de Aristóteles; por muito tempo, para o Cristianismo, o livro foi a Bíblia, mas, ao final da Idade Média, o livro a ser desvendado passou a ser a própria natureza, este artefato divino escrito em caracteres matemáticos. O Novum Organum dos tempos modernos há de colocar o domínio da experiência no foco das atençôes e este foco vai gerar, um século mais tarde, o problema humeano da indução, o qual não encontra mais solução no interior do projeto clássico de conhecimento. ${ }^{26}$ Haverá muitas idas e vindas, porém, a mais extraordinária das quais sendo o probabilismo que os jesuítas tentaram impor nos sécs. XVI-XVII, retomando a doutrina das proposiçóes aceitas segundo o valor das autoridades que as sustentavam. Um resultado, contudo, está garantido: a dialética dos endoxa e seu mundo agonístico de ataque e defesa de ambos os lados do par contraditório, a afirmação e a negação de uma tese, com vistas ao bom estabelecimento dos princípios está definitivamente apartado do conhecimento científico e de seus modos de fundamentação. Em seu lugar se encontra a leitura do Livro - primeiro, dos livros de Platáo e Aristóteles; depois, da Bíblia, o verdadeiro Livro; enfim, do mundo como um livro aberto a ser decifrado em seus caracteres matemáticos. Demorou a acontecer, mas enfim se operou o divórcio entre dialética e ciência.

\section{Bibliografia}

Aristóteles (2002). Física I-II. Tradução de Lucas Angioni. Campinas: IFCH/Unicamp.

Aubenque, P. (1967). La dialectique chez Aristote, in: L'attualità della problematica aristotelica, Pádua, p. 9-3I.

Barnes, J. (1993). Aristotle - Posterior Analytics. Oxford: Clarendon Press.

Berti, E. (1998). As razóes de Aristóteles. Tradução de Dion Macedo São Paulo: Ed. Loyola.

Berti, E. (1997). Philosophie, dialectique et sophistique dans Métaphysique $\Gamma$ 2, in: Revue Internationale de Philosophie 5I.

Brunschwig, J. (2000). Dialectique et philosophie chez Aristote, à nouveau, in: Nestor-Luis Cordero (ed.), Ontologie et Dialogue — mélanges en hommage à Pierre Aubenque. Paris: Vrin, p. I07-I30.

Brunschwig, J. (1967). Topiques $I$ - IV, Belles Lettres.

Fait, P. (20II). Aristotele - Categorie I, in: M. Bonelli e F. Masi, Studi sulle Categorie di Aristotele. Las Palmas: Hakkert Editore, p. 33-50.

Frede, M. (2005). Epilogue, in: The Cambridge History of Hellenistic Philosophy. K. Algra, J. Barnes, J. Mansfeld e M. Schofields (ed). Cambridge, p. 77I-97.

${ }^{26}$ Sobre este ponto, ver em especial Hacking, 1975. 
Hacking, I. (1975). The Emergence of Probability. Cambridge: Cambridge University Press.

Irwin, T. (1990). Aristotle's First Principles, Oxford: Oxford University Press.

Muñoz, A. (2003). "O Aristóteles de Porchat: dogmatismo, ceticismo e história dos sistemas filosóficos”, in: M. Wrigley e P. Smith (eds.), O Filósofo e sua História uma homenagem a Oswaldo Porchat, Coleção CLE Unicamp vol. 36, p. I59-8I.

Porchat Pereira, O. (2000) Ciência e Dialética em Aristóteles. São Paulo: Ed. Unesp.

Porchat Pereira, O. (2004). "Voltando à Dialética de Aristóteles — réplica a Marco Zingano", in: Analytica 8 n. I, p. I43-I88.

Sharples, R. (2010). Peripatetic Philosophy 200 BC to AD 200. Cambridge: Cambridge University Press.

Smith, R. (1993). Aristotle on the uses of dialectic, Synthese 96, p. 335-358.

Smith, R. (1997). Topics I and VII, Clarendon Aristotle Series, Oxford.

Wilkins, A. (1965). Cicero - De Oratore libri tres, Olms.

Wilpert, P. (1956/1957). "Aristoteles und die Dialektik", Kant-Studien 48, 2, p. $247-257$.

Zingano, M. (20I7). Aristóteles - Ethica Nicomachea VI- Is Tratado da Justiça. São Paulo: Odysseus.

Zingano, M. (2004). 'Dialética, Indução e Inteligência na Aquisição dos Primeiros Princípios", in: Analytica 8 n. I, p. 27-4I.

Zingano, M. (2003) "Notas sobre o princípio de não contradição em Aristóteles", in: Cadernos de Filosofia e História da Ciência, Unicamp. 